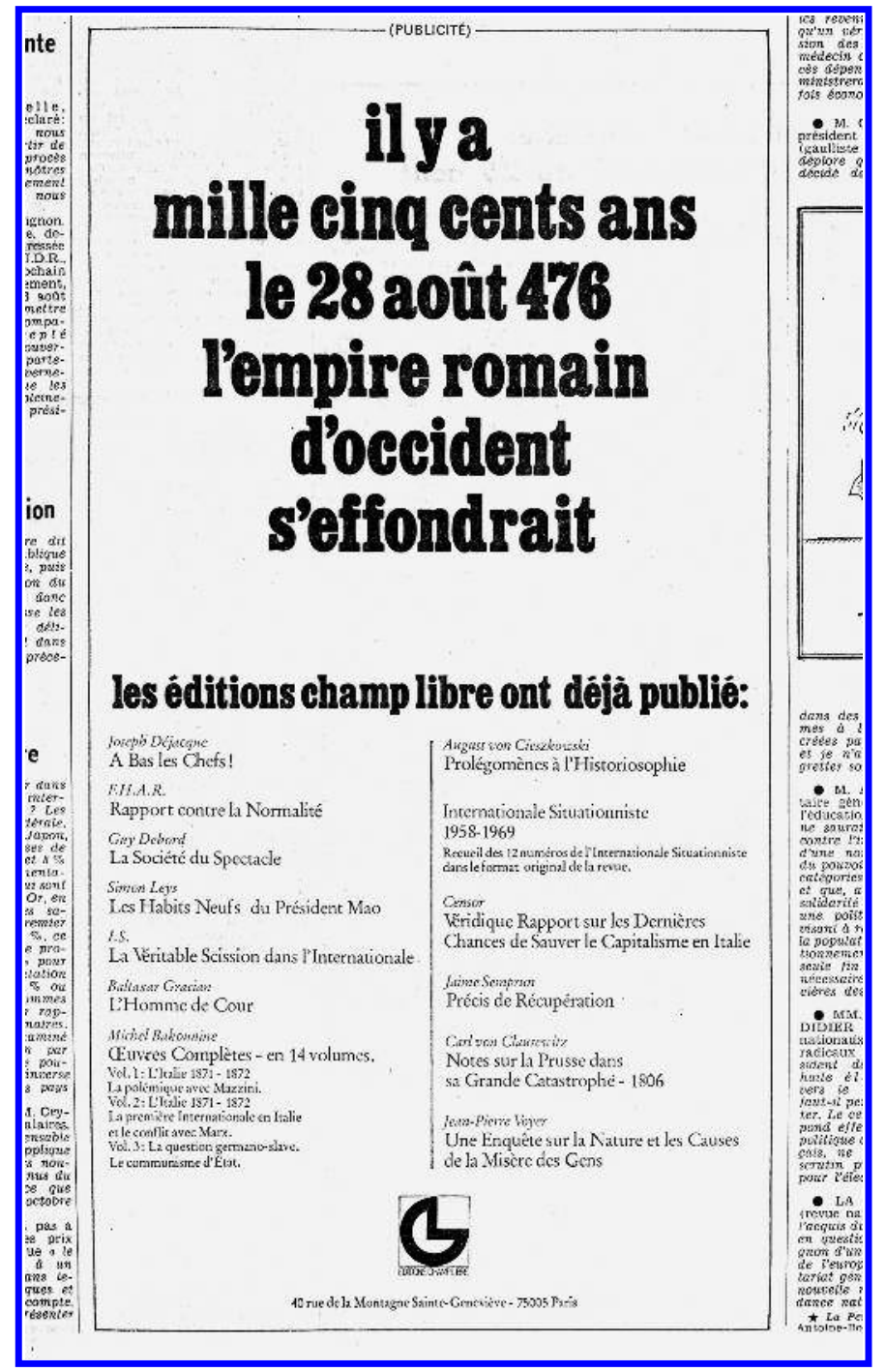




\section{Guy Debord and the Cultural Revolution}

\section{SVEN LÜTTICKEN}

D'ailleurs, c'est moins de formes qu'il s'agit que de traces de formes, d'empreintes, de souvenirs. ${ }^{1}$

One of the crucial tropes of Guy Debord's and of the situationists' practice is the dépassement of specific arts and of art as such. In his film Sur le passage de quelques personnes à travers une assez courte unité de temps (On the passage of a few persons through a rather brief unity of time, 1959), Debord makes a dismissive remark about filmmakers who insist on presenting themselves as auteurs, like "authors of novels" did back in the day. In fact, rather than being elevated to the ranks of art and authorship, "the cinema, too, must be destroyed."2 This avowed desire for destruction notwithstanding, the tendency to reevaluate Debord's cinematic work that was inaugurated by Tom Levin's 1987 essay has become much more pronounced since Debord's death. ${ }^{3}$ This development has been helped by the fact that we now have access to Debord's films, which at the time of Levin's essay had largely been withdrawn from circulation. That is, a "body of work" is now available to us. But perhaps work should here be read as travail rather than as oeuvre (d'art), as activity rather than result. In Sur le passage, Debord notes that his subject was "the collective art of our time" and that "An art film on this generation can only be a film about its lack of real creations [l'absence de ses oeuvres]." ${ }^{4}$ As the Russian productivist critic Nikolai Tarabukin wrote (in a book published by Champ Libre, the publisher with which Debord was closely associated), "the art of the future will not consist of luxury items but of transformed labor."

In Sur le passage, Debord uses the term activité esthétique as a synonym for art, but when examining Debord's practice much is to be gained from making a distinction between art and the aesthetic and using the notion of aesthetic activity or practice as one that problematizes the existence of art as a separate social sphere. If one element can be found in all forms of Marxian aesthetics, it is-in Hans Magnus Enzensberger's wordsthe promise of "an aesthetic which is not limited to the sphere of 'the artistic."” 6 When Karl Marx predicted (or demanded) that under Communism painters, people exclusively devoted to the profession of painting, would be replaced by people who also paint, he was announcing the transfor- 
mation of work as the aesthetic project par excellence. ${ }^{7}$

Neither Marx's nor Debord's imagined future came to pass, but Debord's praxis has contributed significantly to our understanding of the transformation of work in general and of aesthetic labor in particular. My subject here is not limited to Debord as filmmaker or to Debord's films; rather, I focus on Debord as an aesthetic activist whose cinematic and other oeuvres are equally absent and present. I discuss films such as In girum imus nocte et consumimur igni (1978) as stand-ins for "absent works" whose problematic status is part of the point. We can see or read some of his "works," we can publish or screen or exhibit them, but they exist as something both more and less than tangible facts. They are performance rather than object. In this they mirror more-general transformations of capitalism during the 1960s and 1970s, but Debord's practice pushes performance to the point where it becomes a form of action turned against the performative regime itself. In this sense, In girum was not actually Debord's final word on the cinema, because he continued to be involved in the "performing" of his oeuvres cinématographiques.

\section{New Forms of Action in Painting and Publishing}

In the crucial period when the Situationist International (SI) ridded itself of the "Nashist" and "Spurist" tendencies (the years 1960-1962), the central point of contention was the status of art as a field that depended on the production of a specialist type of commodity. ${ }^{8}$ Whereas "the artists" wanted to cling to established artistic media and formats- such as painting-Debord and his allies sought to negate such conventional forms through an avant-garde aesthetic of transgressive actions. But what remains when art is negated? One answer is that the negation of art is itself an aesthetic and political action.

A few artifacts were left behind by the SI. An object such as the poster for the 1962 SI conference in Antwerp, with its detourned image of Marilyn Monroe, is not just a critical negation of film posters and stills but also of the rarified painting-commodities produced by the artists of the "other" SI: namely, the "Nordic" group around Asger Jorn and Jørgen Nash. More explicitly and hence polemically, Debord would challenge the Nordic painters head-on with his 1963 series of Directives, which consisted of painted slogans on canvas (one was a reused piece of industrial painting by a former member of the SI, Giuseppe Pinot-Gallizio). The Directives were shown at the exhibition Destruction of the RSG-6, in Odense-an attack on the Scandinavians in their own backyard. ${ }^{9}$ Saluting actions by Spies for Peace in the UK, who made public the secret plans for an atomic fallout shelter to be used by the government ("RSG-6"), the SI organized the antinuclear exhibition Destruction of RSG-6 in order to 
reclaim art from the Nashists for the Debordian SI—and to do so by lauding destructive anti-art gestures. The show included "works" that detourned both modern painting and the iconography of the Cold War, as in J.V. Martin's quasi-expressionist “Thermonuclear Paintings.” In a crucial text written on the occasion of Destruction of the RSG-6, "The Situationists and New Forms of Action in Politics and Art," Debord affirms the rejection of "Nashist "situationism"” as a "falsification," while at the same time acknowledging the "perpetrators" of certain "new radical gestures as being situationist," promising "to support them and never disavow them, even if many among them are not yet fully aware of the coherence of today's revolutionary program, but are only moving in that general direction." 10 Among the "acts that have our total approval" was the attempt by revolutionary students in Caracas to take hostage paintings from an exhibition of French art and use them as collateral. A subsequent bomb attack on a police van transporting the recovered paintings "unfortunately did not succeed in destroying it." 11

Debord enthused that this

is clearly an exemplary way to treat the art of the past, to bring it back into play in life and to reestablish priorities. Since the death of Gauguin ("I have tried to establish the right to dare everything") and of Van Gogh, their work, coopted by their enemies, has probably never received from the cultural world an homage so true to their spirit as the act of these Venezuelans. ${ }^{12}$

Recalling Mikhail Bakunin—who in 1849 had proposed to place paintings from the museums on the barricades, "to see if this might inhibit the attacking troops from continuing their fire"-Debord notes that the Caracas skirmish "links up with one of the highest moments of the revolutionary upsurge of the last century, and even goes further." ${ }^{13}$ Here the fetish of the "Nashists," the easel painting, is subjected to a terrorist attack.

Jorn and other situationist painters were likewise engaged in a struggle with the Western tableau, the history of Western painting, and the antinomies of artistic production in the society of the spectacle; however, they did so immanently, within the medium of painting itself. By contrast, for Debord to pay "homage" to the "spirit" of heroic modernists such as Paul Gauguin or Vincent van Gogh necessitated an external attack on painting and a critical rejection rather than an immanent critique. However, such an attack would not necessarily be extra-aesthetic. A "normal" revolutionary group would hardly deem paintings a prime target for revolutionary action. Indeed, in the same text Debord insists that the SI can be seen "as an artistic avant-garde" as well as 
an experimental investigation of possible ways for freely constructing everyday life, and as a contribution to the theoretical and practical development of a new revolutionary contestation. From now on, any fundamental cultural creation, as well as any qualitative transformation of society, is contingent on the continued development of this sort of interrelated approach. ${ }^{14}$

The aim of the project of the dépassement de l'art-as inscribed on one of the Directives exhibited in Odense-was not so much to abolish art as to actualize its potential in society, in life, as aesthetic praxis. Art as Weberian sphere had to go in favor of a lived aesthetic practice. As Debord wrote in 1958 in his "Theses on Cultural Revolution," "Art can cease to be a report on sensations and become a direct organization of higher sensations. It is a matter of producing ourselves, and not things that enslave us." 15 What Debord terms cultural revolution needed to be complemented by or be the complement and completion of a social and political revolution. In a statement on cultural revolution written in the context of the SI's 1959 Munich conference, André Frankin notes that

capitalism has separated [artists] from culture, substituting what should be the real practice of life with false modes of life and leisure. To this false dichotomy of technology and culture is born a false unitary vision of civilization. The future and the present of every political and social revolution depend above all on the consciousness of this second alienation, more profound and more intractable than economic alienation. ${ }^{16}$

Cultural alienation necessitates a cultural revolution. An alliance of sorts between the alienated artists and the alienated proletariat was therefore essential to any revolution worthy of the name.

Whereas the term cultural revolution would have a significant career following the upheavals of 1967 and 1968, and was used extensively in German "actionist" and New Left circles, for the situationists the concept had become tainted, not least because of the Maoist connotations that were hard to avoid after $1966 .{ }^{17}$ For the situationists, only idiots could think "something [was] 'cultural' about this affair [the Chinese Cultural Revolution]," because it was merely window dressing for a power struggle. ${ }^{18}$ By contrast, aiming at a full-blown cultural revolution rather than a mere takeover of the state, the avant-garde of the 1960s reexcavated the aesthetic promise of Communism. Politicizing Friedrich Schiller's On the Aesthetic Education of Man, Marx had envisaged the end of the division of labor as making possible a more sensuously rich and diverse existence. 
What united a number of groups in the New Left and the avant-garde in the 1960s was the insight that culture could no longer be seen as a mere superstructural/ideological reflection of the base. The productive forces were no longer exclusively industrial, and the culture industry and the media were themselves as much base as they were superstructure. Hence-to summarize a series of complex and contentious debatesartists and students were potentially as much of a revolutionary class as the proletariat. Marx had already argued that capitalist technology turned knowledge into a productive force, and in the late 1960s his notion of the "general intellect" from the Grundrisse became crucial for theorists of "new forms of action" such as Hans-Jürgen Krahl, who tried to forge new alliances. ${ }^{19}$ Student movements in various countries appeared to show the revolutionary potential of the cognitariat, with May 1968 in France being the locus classicus.

Debord's position regarding May 1968 is paradoxical. On the one hand, he and the SI had been instrumental in calling attention to cultural activism as (potentially) political and revolutionary; on the other hand, while Debord remained interested in the radicalism of bohemians and the classes dangereuses, he never really addressed the decline of the classic industrial proletariat and its consequences for the revolutionary project. Debord tended to ignore or minimize the social changes that were taking place during his lifetime, especially the decomposition of the classic proletariat and the effects of this development on the chances of a revolution. While Debord had always accorded an important role to bohemian intellectuals, artists, and antisocial elements, he left to others in France and elsewhere-including the Dutch Provos and various German and Italian theorists-the task of articulating more fully the perspective of a postclassical revolutionary politics. For a long time after May 1968, Debord remained on the lookout for signs of a revolution to come, and his conception of the revolution was not without classicizing traits-traits that also characterized his literary preferences.

From 1971 onward, Debord forged an ever-closer working relationship with Gérard Lebovici's Champ Libre publishing house, which had been created in the aftermath of May 1968. Champ Libre not only became the primary publisher of Debord's writings but also reflected his preferences in its overall program. Although Debord bristled at the suggestion that he was Champ Libre's éminence grise, he played exactly this role and with gusto. ${ }^{20}$ To some extent, Champ Libre and its successor, Éditions Gérard Lebovici, came to function as a library of Debord-approved classics, from the revolutionary Anacharsis Cloots to the Hegelian August Cieszkowskiwhose theory of the act made an impact on the early Marx-to the 
seventeenth-century Cardinal de Retz, with a heavy helping of Russian avant-garde. ${ }^{21}$ Champ Libre was defiantly historical and even historicist. In 1986, when Éditions Gérard Lebovici opened a bookstore on its new premises in the rue Saint-Sulpice, Debord devised a program for "thematic vitrines" with regularly changing displays of the publisher's books-focusing, for instance, on the avant-garde, "Hegelo-Marxism," anarchism, Spain, or military strategy. ${ }^{22}$ In these historical permutations, a book could appear in different contexts, foregrounding various aspects. Debord played with the publisher's backlist-shaped by his own interests-in what amounts to a curious form of action below the radar of most positions in politics or art; it is an anachronistic performance that reflects a redefinition of labor pioneered but never fully theorized by Debord. In a media-saturated economy, books need to be staged as events, and authors need to become performers of their work. Champ Libre resolutely rejected this, even to the point of refusing to send review copies to the press. The understated displays suggested by Debord were pithy anti-events that performed the back catalog in ways that were sure to pass largely unnoticed. The ongoing cultural revolution retreated into ever more marginal forms of action, though with the occasional splash: in an ad published in Le Monde on Saturday, August 28, 1976, Champ Libre commemorated the collapse of the Western Roman Empire on August 28, 476-and proceeded to plug books by authors including Bakunin, Cieszkowski, Clausewitz, and Debord, all of whom were supposedly hastening the collapse of capitalism..$^{23}$

Minor though it may be, Debord's "curatorial" activity for his publisher's bookstore suggests that for him cultural production-in this case, publishing - was not limited to the production of certain artifacts but encompassed the "performance" of these artifacts and through this ultimately the production of specific modes of reception and use. The specificity of these modes potentially turns Debordian performance into one of the forms of action Debord theorized. As Marx writes in the Grundrisse,

Hunger is hunger, but the hunger gratified by cooked meat eaten with a knife and fork is a different hunger from that which bolts down raw meat with the aid of hand, nail and tooth. Production thus produces not only the object but also the manner of consumption, not only objectively but also subjectively. Production thus creates the consumer. ... The object of art-like every other product—creates a public which is sensitive to art and enjoys beauty. Production thus not only creates an object for the subject, but also a subject for the object. ${ }^{24}$ 
Louis Buffier. Les conseils superflus (Unnecessary advice), 1950 s or early 1960 s. Postcard showing Guy Debord's graffito "Ne travaillez jamais" (Never work).
But if this is a general characteristic of production, the nature of production changed during the period in which Debord practiced his version of the cultural revolution. The industrial production of goods was increasingly supplemented and partially supplanted by the production of subjectivity through cognitive or immaterial labor. Producing became forever reperforming texts and images.

Debord participated in and responded to this shift when, for instance, he replied in 1963 to a letter from the Cercle de la Librarie demanding money for copyright infringement. Debord was accused of having taken the photo of the "Ne travaillez jamais" (Never work) graffito published in Internationale situationniste from one of a series of postcards of Parisian scenes with "funny" captions-as in fact he had. In response Debord argued that because he was the author of the original graffito back in 1953 (something for which he claimed he could produce several witnesses), the photographer and the publisher had infringed his copyright. Rejecting the whole of intellectual property law, Debord then magnanimously promised not to press charges himself, but he insisted that the publisher remove the "funny" caption "Les conseils superflus" (Unnecessary advice) from the card. ${ }^{25}$ As he had probably anticipated, Debord never heard from the publisher again.

As ephemeral graffito, "Ne travaillez jamais" was beyond recuperation, hardly an oeuvre. As the picture postcard Les conseils superflus subsequently detourned by the SI, however, the piece becomes work, is put to work. In reprinting the photo (albeit cropped and shorn of its offensive legend) and engaging in a correspondence (that has now been published as part of his Correspondance), Debord assisted in its transformation. Debord engaged in a legal skirmish not just to prove that the copyright of the slogan was really his but to stress that he rejected the entire legal framework of copyright. By engaging in this exchange and writing a lengthy letter, Debord effectively participated in the redefinition of work and turned performative "semiotic" labor into a form of action.

However, the articulation of conflicts and antinomies is itself a crucial part of the new labor, a way of turning performance into a form of action. If some of these conflicts became apparent only years after the fact, Debord was instrumental in publishing the Correspondance of Champ Libre precisely in order to show what goes on behind the scenes, to show the reality of this far-from-generic cultural enterprise-which cultivated the art of the insult as part of its own version of the reinvention of work. ${ }^{26}$ 


\section{Against the Cinema}

His work as film director to some extent forced Debord to play the game of intellectual property-even if he played it with the aim of upending it. For his films, in particular those produced by Lebovici during the 1970s, Debord made lists of films he wished to detourn, and attempts were made to secure the rights. In his final film, In girum imus nocte et consumimur igni, Debord included extensive footage from the 1936 version of The Charge of the Light Brigade in order to "illustrate" the battles of the situationist avant-garde. Earlier, he had tried to include part of the 1968(!) color remake in his film version of La société du spectacle (The Society of the Spectacle). The copyright holder, however, proved to be excessively suspicious, and nothing came of it. ${ }^{27}$ While an extended sequence in In girum was culled from the 1936 film, a short clip from the remake turns up toward the end of the film, but in black and white. The montage in films such as La société du spectacle and In girum is thus shaped by commercial negotiations; this is, so to speak, embedded détournement.

By detourning the films, Debord screens or performs them in a specific manner, as part of his montage. But how are the films that are thus produced shown in turn? Film has to be performed in order to be seen, to appear. A roll of celluloid in a can is nothing; it has to be projected under certain conditions. As Mary Ann Doane emphasizes, film has a double existence: as stored and as projected film. ${ }^{28}$ In Doane's words, "the cinema generates a confusion about the location of the image, abstracting location itself. The virtuality of the image indicates not a question about its substance or materiality, but an undecidability as to where it is."29

Where and when was Debord's cinema, which is now freely available to us but no longer in cinematic form? The regular cinema screening situation was profoundly problematic for Debord, as the epitome of the spectacle and of the reign of fetishism and separation. Two images in particular encapsulate his and the SI's problematization of cinema as a spectacle in which captive spectators with impoverished lives project their desires onto actor-fetishes.

The first is the image captioned "London, 1960: Situationists at the Cinema" in the Internationale situationniste. Various photos of this tableau are known to exist, taken from different angles. ${ }^{30}$ They all show a group of situationists in London at the ICA cinema/auditorium, illuminated starkly from the front by the projector beam, with the white screen behind them. The image suggests an audience standing in the light of Debord's Hurlements en faveur de Sade (Howls for Sade, 1952), which was shown at the theater in June 1960. The photo-or rather, series of photos-was taken in September, on the occasion of the SI conference in 
London. During the conference, SI members staged a demonstration and debate at the ICA that excruciated the audience with endless delays over translations and ended when the situationists left in protest after an audience

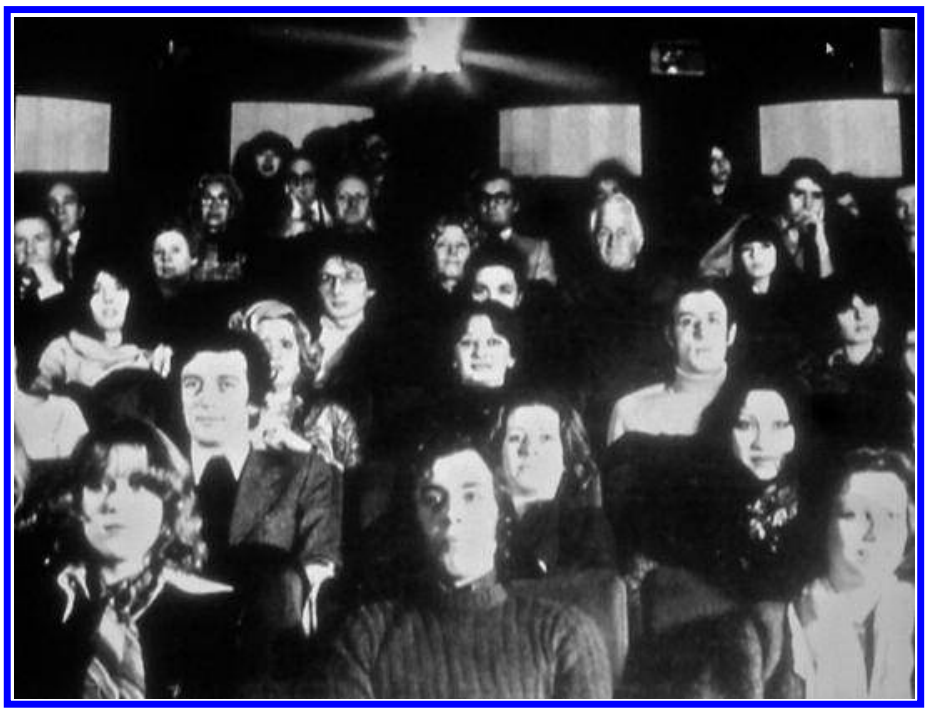
member asked for the definition of the term situationism. ${ }^{31}$ As an exercise in audience provocation, the ICA debate recalls screenings of Hurlements. Guy Atkins recalls SI members in the first rows making catcalls while Maurice Wyckaert read out the SI's statement-translated by Atkins on Debord's behest into a highly literal, and hence all but incomprehensible, English-with a heavy Flemish accent. ${ }^{32}$ Here assembled for a photo shoot in front of the screen, the situationists (minus Debord) are lit up by the cinema, but as acting subjects refusing to buy into the spectacle of Hollywood's prized actors they relegate film to the status of mere backdrop. ${ }^{33}$

The second image is a photo of "A contemporary movie audience, photographed from the screen at which they are staring fixedly, so that the spectators find themselves face to face with nothing but themselves." This us how the image is described in the script of In girum. ${ }^{34}$ Unlike the photo of the 3-D movie audience used for the U.S. edition of The Society of the Spectacle, this audience-in-the-movie looks directly at the viewersin-the-auditorium. This photo of a movie audience is, after all, meant to be seen in the cinema, as part of In girum. This image is a mirrorical return, to use a Duchampian phrase. The question quickly becomes one of identity: Do the viewers of In girum face "themselves," or might they be or become something other than a generic "contemporary cinema audience," a different kind of collective entity? Seeing In girum now on DVD hardly gives the same sense of interpellation. If Debord is a master of montage, the montage includes not only the often highly layered audiovisual montage of his films, with their dialectical interaction between still and moving images, inter- and subtitles, monologues and other sounds; it also includes the montage of film and audience, of film and screening situation. In short, Debord's montage is also a form of social montage.

La société du spectacle and In girum, both produced by Lebovici's Simar Films, were released with some fanfare-even if, by film industry standards, it was a marginal sort of fanfare. Debord prided himself on the “triumphant” premiere of La société du spectacle on May 1, 1974, before an audience of laborers and marginaux. ${ }^{35}$ Here, in the politically charged context of May Day and a nonbourgeois (and antibourgeois) audience, the project of a countercinema seemed to become a momentary reality. 


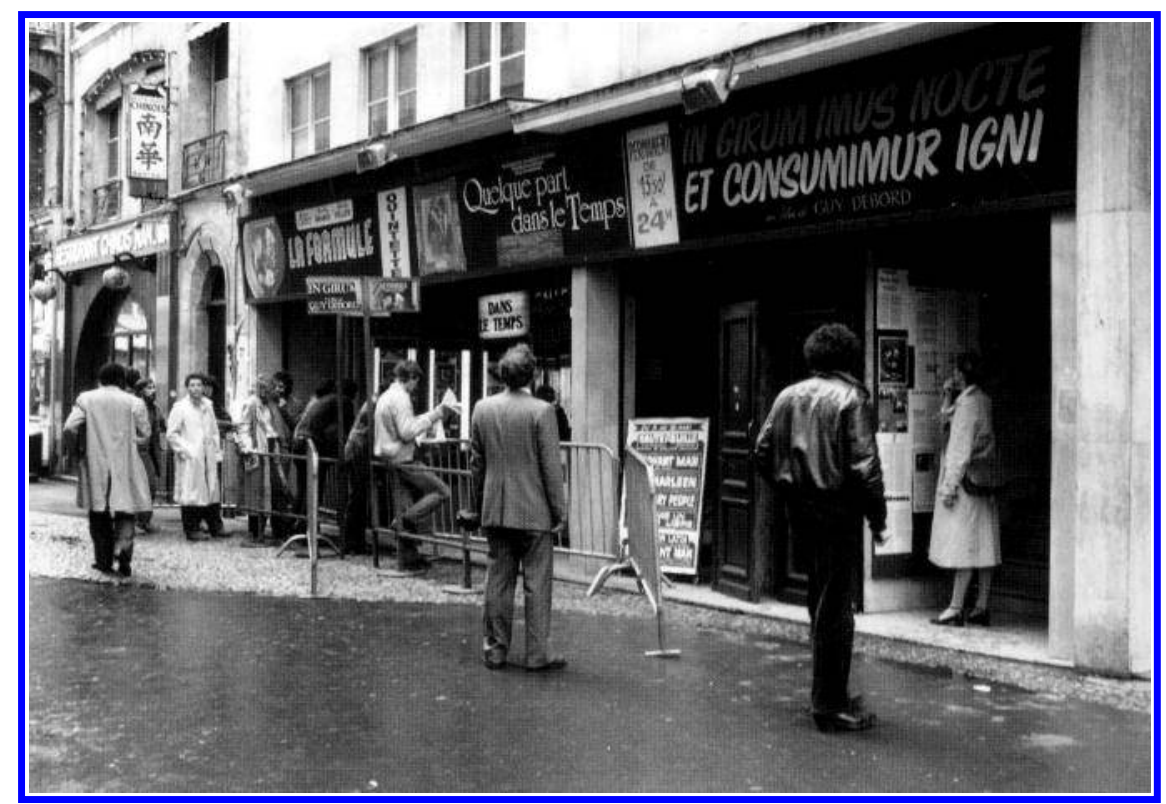

In girum, however, would contain a grim indictment of the "regular" cinema audience-represented by the photograph of the "contemporary movie audience":

The movie-going public, which has never been very bourgeois and which is scarcely any longer working-class, is now recruited almost entirely from a single social stratum, though one that has been considerably enlarged-the stratum of low-level skilled employees in the various "service" occupations that are so necessary to the present production system: management, control, maintenance, research, teaching, propaganda, entertainment, and pseudocritique. Which suffices to give an idea of what they are. This public that still goes to the movies also, of course, includes the young of the same breed who are merely at the apprenticeship stage for one or another of these functions. ${ }^{36}$

In girum was released, with some delay, by Gaumont in 1981. A photo of a cinema in the Quartier Latin shows it playing alongside a Hollywood film of the day, Quelque part dans le temps (Somewhere in Time). ${ }^{37}$ This incongruous montage is not without its own charm, but soon Lebovici would give Debord the opportunity of having a small cinema dedicated to his films: Lebovici bought Studio Cujas in Paris, and Debord determined the sequence in which his films were to be shown there on a weekly basis. The films were to be projected-performed-even if an audience failed to materialize; the films would be shown to an empty house. ${ }^{38}$ A somewhat idiosyncratic episode, no doubt-but all the more interesting for that. Just when a certain cinema culture that had blossomed in the 1960s and early 1970s was in terminal decline, with the video geek replacing the old cinephile, Debord created a completely dysfunctional performance of film. The Cujas séances played to a different counterpublic than that of the (sub-)proletarian May crowd, and at times it was a counterpublic of absence, one that did not in fact exist in the desert of the present. Here a failed performance became a form of action that had no immediate social or political effect but prided itself on being 
a genuine avant-garde action precisely because it was utterly uselessa little potlatch, a sovereign gesture.

In Debord's films-particularly Sur le passage and In girum-one finds an insistence that they pertain to a lost world, being paeans to lost groupings and comrades. This insistence brought with it certain formal strategies. In Sur le passage, the camera pans across photographs of young bohemians as a mockery of films d'art. A café scene resembling one of these photos is then restaged for the film-a "reconstitution pauvre et fausse comme ce traveling manqué."39 The "documentary" photo that serves as cliché footage for an art film must be as impoverished and false as the botched tracking shot of a reenacted drinking session. In girum embroiders further on the same theme, reusing some of the same photos as well as scenes showing Zorro in action and The Charge of the Light Brigade in combination with tracking shots of the waterfront of Venice, which were recorded specifically for the film. With In girum, Debord claims to be stating

a few truths over a background of images that are all trivial or false. This film disdains the image-scraps of which it is composed. I do not wish to preserve any of the language of this outdated art, except perhaps the reverse shot of the only world it has observed and a tracking shot across the fleeting ideas of an era. What needs to be proved by images? Nothing is ever proved except by the real movement that dissolves existing conditions-that is, the existing production relations and the forms of false consciousness that have developed on the basis of those relations. ${ }^{40}$

A great deal more could be said about the polyphonic montage of different kinds of images and Debord's monologue d'ivrogne in In girum. Benjamin Noys has analyzed some of the recurring images and their interrelations. For example, photos of the grid for Debord's Le jeu de la guerre ( The Game of War), a board game he conceived, echo photos of angular, modular sofas seen elsewhere in In girum, as well as aerial photographs of Paris. ${ }^{41}$ As the historical battlefield par excellence for Debord, Paris had irregularities and specific qualities deriving from its singular history-even though the aerial photos transform the lived reality of Paris into crystalline images. ${ }^{42}$ By contrast, Le jeu de la guerre as an abstract model of conflict appears to replicate, as artist Rod Dickinson says, "the abstraction of capitalist space that is founded on networks of banks, business centres and information lattices, rather than space with specific, local character." ${ }^{43}$ Debord had a small edition of the board game made in 1977, just in time to be photographed for In girum, and in March 1978, while working on the film, Debord wrote to Lebovici that cinema 
was "finished" and that a mass-market edition of the game should be released as soon as possible. ${ }^{44}$ Even if the Studio Cujas episode and a 1982 contract Debord signed with one of Lebovici's companies to make a film about Spain show that Debord did not completely abandon the cinema as a field of action, at the time of In girum, Le jeu de la guerre was presented as the next step after the fin de cinéma.

\section{Games after Play}

As Dickinson, a member of the Class Wargames group, notes in an essay on Debord's Jeu de la guerre, the game, with its ruthless rules trapping players time and again, appears to be "the very antithesis of Debord's earlier proclamations on the Situationist approach to play, where winning is 'the wretched product of a wretched society." "45 The Lettrist International and early SI were marked by "ludic" rhetoric; the aim of the grand jeu of revolutionary aesthetic action was to produce an unalienated life of play. In this context, the cinema, with its passive spectatorship rather than active involvement, became the enemy par excellence. If the spectacle is the reign of separation and passivity, play is seen as a counterspectacle in which the division between actors and spectators is sublated. And because cinema is the epitome of spectacle, play opposes cinema. The cinema spectator had to become an actor-not a film actor but an actor in the unscripted play of his or her own life. ${ }^{46}$

As a game, and a game of war no less, Debord's Jeu de la guerre should be distinguished from the early situationist hymns to play, to play unbound, to a life without rules-or at least with only moral, rather than conventional social or economic, rules. The game was a tool for sharpening one's strategic skills in the struggle for a life that would indeed be play unbound, but had yet to be realized. While Le jeu de la guerre was allegedly developed in the 1950s and patented in 1965 (Debord playing the game of intellectual property for the occasion), his 1970s attempt to promote and market the game fits his "strategic turn" in that decade. Clausewitz became a crucial point of reference for Debord in the 1970s (Champ Libre published Clausewitz in translation during this period), and Debord's Jeu de la guerre ultimately harks back to Clausewitz's own social circle-to the Kriegsspiel (war game) constructed by the Prussian official Georg Leopold von Reiswitz in 1812. ${ }^{47}$ However, Debord stated that his game ultimately reflects a pre-Napoleonic, eighteenth-century mode of warfare. Playing Le jeu de la guerre is a strange experience. Not particularly engaging as a board game, it becomes a historical game in a different way. If we do not see it as merely a symptom of retreat, a flight from history into historicism, we might say that it operates differently from "normal," successful games. Going over moves and strategies in an 


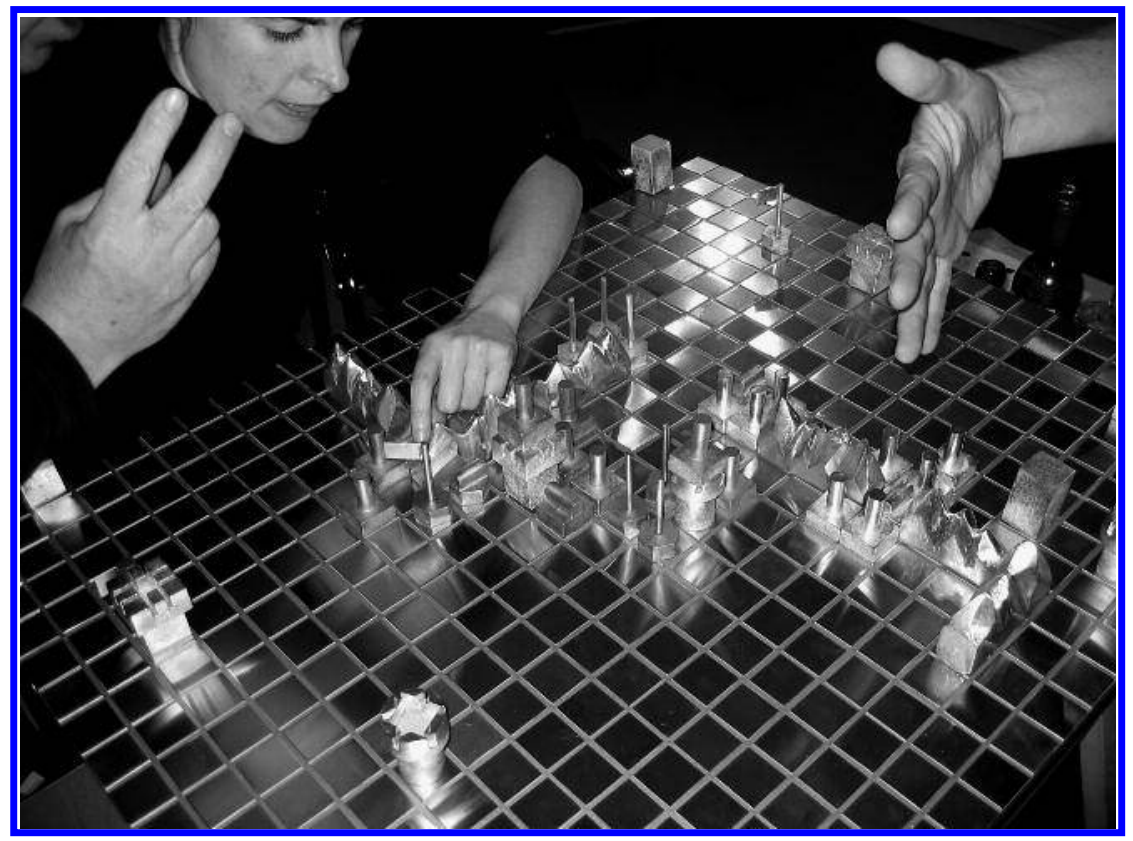

archaic setting becomes a play with history.

In addition to the recent English-language edition of the game and its manual, the groups Class Wargames and Radical Software have created their own versions. The game derives some of its surprising contemporary relevance from its break with the ludic ideology of the neo-avantgarde, an ideology that has proved to be compatible with capitalism's own "ludic turn" in recent decades. In the age of Facebook and Instagram, creative involvement is itself the rule. Welcome to the new labor, in which ludic play works in the service of economical games. Today's performative labor mocks Marx and Debord alike in appearing to transform work into play-though this play is an economic game.

The ludism of the neo-avant-garde coincided with an increasing dominance of games-rather than play-in economic theory. As Pamela M. Lee writes, this game theory "[has] nothing to do with the ludic," revolving rather around bargaining and decision-making in military as well as economic contexts. ${ }^{49}$ Like cybernetics, which was the subject of situationist attacks in the 1960s, game theory analyzes information in terms of loss and gain, efficiency and rationalization. If the situationists demanded new forms of play that could not be contained by any fixed set of rules, game theory was very much dependent on such rules, on the permutations of a limited set of options and on the analysis and development of strategies that depend on feedback to one's moves in this delineated field of possibilities-feedback in the form of the move made by an opponent who may or may not be human. Norbert Wiener warned that "there are in existence government agencies bent on applying [the theory of games] to military and quasi-military aggressive and defensive purposes." 50

Class Wargames, which stages public matches with a version of Debord's Jeu de la guerre produced by Dickinson, created an online film about the game which states that every player should study the strategy employed by Frederick the Great during the Seven Years' War-the monarch's focus on good lines of supply and communication having influenced twentieth-century warfare and its technological apparatuses. ${ }^{51}$ Debord's 
emphasis on lines of communication could be seen as a "cybernetic" modernization of the game- even though Debord cited the Seven Years' War as his historical model. ${ }^{52}$ As Dickinson stresses,

"The Game of War" departs from the traditional game of Kriegsspiel by utilising a system of communication relays to keep pieces in play and active.... As a player you quickly discover that the road to victory is by smashing your opponents' communication network, rather than trying to eliminate his or her players. The game only needs the addition of PR companies employed by contemporary armies to complete a 21st century depiction of warfare..$^{53}$

Debord's game, then, would not be a completely alien entity in today's age.

However, perhaps the outmoded elements of Debord's own war game are more valuable than this "contemporary" aspect. The digital version of the game created by the Radical Software Group stresses its alterity; it could not be more different from first-person shooter games or, as Alexander Galloway stresses, from real-time strategy games and swarm games. ${ }^{54}$ With their multiple actors and multiplicity of events unfolding in real time, such games are far removed from the chess-like sequences of Debord's game, unfolding in an abstract temporality ruled by two commanders who move around the troops of history. Although Debord rejected game theory and its math-based bargaining and although his game aims to teach us to shatter the perpetual present of such zero-sum games, his game of strategy has more in common with game theory than he would have cared to admit. In fact, Debord tended to conceive of revolutionary history as a finite game with narrowly defined rules.

Like the Studio Cujas film "performances" or the book "events," Le jeu de la guerre is another instance of late Debord at his most problematic and most essential. The game today is an aesthetic "form of action" that is as new as it is obsolete; to play it is to be stuck between historical moments that all seem equally blocked. In thus reactualizing Debord's anachronistic relevance, the experience of Le jeu de la guerre can serve as a warning against normalizing some of Debord's other activities. The increasing scholarly focus on Debord's films should not turn them into manageable oeuvres-into classic essay films, for example. Even while analyzing the intricacies of Debord's dialectical montage, we must notice that, to paraphrase Paul Chan, these films are works that work precisely insofar as they do not quite work. ${ }^{55}$ Debord's practice does not meet the standards of economy and productivity that tacitly underpin many aesthetic judgments. His acts are not efficient; whatever agency they have rests in this. 


\section{Notes}

1. "And we are dealing not so much with forms as with traces of forms, with imprints, with memories." Subtitle in Guy Debord, Critique de la séparation [film script] (1961), in Oeuvres cinématographiques complètes (Paris: Gallimard, 1994), 54.

2. Guy Debord, "On the Passage of a Few Persons through a Rather Brief Unity of Time [film script]," trans. Ken Knabb, Bureau of Public Secrets, http://www.bopsecrets.org/ SI/debord.films/passage.htm. For the original French, see Guy Debord, Sur le passage de quelques personnes à travers une assez courte unité de temps [film script] (1959), in Oeuvres cinématographiques complètes (1994), 35.

3. Thomas Y. Levin, "Dismantling the Cinema: The Films of Guy Debord," in On the Passage of a Few People through a Rather Brief Moment in Time: The Situationist International 1957-1972 (Cambridge, MA: MIT Press; Boston: ICA, 1989), 71-121.

4. Debord, "On the Passage [film script]"; and Debord, Sur le passage [film script] (1959), in Oeuvres cinématographiques complètes (1994). At first glance, the voluminous Gallimard edition of Debord's Oeuvres seems to contribute to a reactionary normalization and co-optation of Debord's life, turning him into a "classical author" (admittedly, Debord himself did increasingly exhibit classicizing tendencies). However, the book makes a great effort to present highly divergent types of text (film scripts, books, articles, letters, various documents)—and some images (film stills)—as manifestations of Debord's “art de vivre." See Alice Debord, introduction to Oeuvres by Guy Debord (Paris: Gallimard, 2006), 10. Debord had already published his Oeuvres cinématographiques complètes (Paris: Champ Libre, 1978)—oeuvres that include his remark on the absence of proper oeuvres.

5. Nikolaï Taraboukine, Le dernier tableau: Du chevalet à la machine: Pour une théorie de la peinture (Paris: Champ Libre, 1972), 56. This publication, edited by Andrei B. Nakov, was published when Debord's position at Champ Libre was not yet as dominant as it would later become. In a 1975 letter to Gérard Lébovici in which he critically reviews Champ Libre's past publications, Debord singled out for praise a number of books by authors including Carl von Clausewitz and Mikhail Bakunin, as well as George Kubler and Tarabukin's Le dernier tableau — specifying that he had not yet read the latter but was relying on the judgment of "people with taste." Guy Debord, Correspondance, vol. 5 (Paris: Arthème Fayard, 2005), 264.

6. Hans Magnus Enzensberger, "Constituents of a Theory of The Media," New Left Review 64 (November/December 1970): 25.

7. Karl Marx and Friedrich Engels, Die deutsche Ideologie (1845-1846), in Werke, vol. 3 (Berlin: Karl Dietz Verlag, 1990), 379.

8. In the SI's idiom, "Nashist" refers to the mostly Scandinavian situationists around Asger Jorn's brother, Jørgen Nash, who split from the SI on March 15, 1962. "Spurist" refers to the Gruppe Spur, which functioned as the German section of the SI until its members were excluded on February 10, 1962.

9. See Mikkel Bolt Rasmussen, "To Act in Culture while Being against All Culture: The Situationists and the 'Destruction of RSG-6,"' in Expect Anything Fear Nothing: The Situationist Movement in Scandinavia and Elsewhere, ed. Mikkel Bolt Rassmussen and Jakob Jakobsen (Copenhagen: Nebula; Brooklyn: Autonomedia, 2011), 75-113.

10. Guy Debord, "The Situationists and the New Forms of Action in Politics and Art" (1963), trans. Ken Knabb, Bureau of Public Secrets, http://www.bopsecrets.org/SI/newforms.htm.

11. Debord, "The Situationists and the New Forms of Action." 
12. Debord, "The Situationists and the New Forms of Action."

13. Debord, "The Situationists and the New Forms of Action."

14. Debord, "The Situationists and the New Forms of Action."

15. Guy Debord, “Theses on Cultural Revolution,” trans. Ken Knabb, Bureau of Public Secrets, http://www.bopsecrets.org/SI/1.cultural-revolution.htm; emphasis added. For the original French, see Guy Debord, “Thèses sur la révolution culturelle,” Internationale situationniste 1 (June 1958): 21.

16. André Frankin, "Platform for a Cultural Revolution," trans. Reuben Keehan, Situationist International Online, http://www.cddc.vt.edu/sionline/si/platform.html. For the original French, see André Frankin, "Plate-forme pour une révolution culturelle," Internationale situationniste 3 (December 1959): 25.

17. For example, issue 16 (1969) of the German left-wing Kursbuch (edited by Hans Magnus Enzensberger) contains a section on Kulturrevolution with texts by Walter Kreipe and Peter Scheider, the latter titled "Die Phantasie im Spätkapitalismus und die Kulturrevolution” (1-37).

18. "The Explosion Point of Ideology in China," trans. Ken Knabb, Bureau of Public Secrets, http://www.bopsecrets.org/SI/11.China.htm. For the original French, see "Le point d'explosion de l'idéologie en Chine," Internationale situationniste 11 (October 1967): 5.

19. See Karl Marx, Grundrisse der Kritik der politischen Ökonomie (1857-1858), in Karl Marx and Friedrich Engels, Werke, vol. 42 (Berlin: Karl Dietz Verlag, 2005), 602. See also Hans-Jürgen Krahl, "Produktion und Klassenkampf” (1970), in Konstitution und Klassenkampf: Zur historischen Dialektik von bürgerlicher Emanzipation und proletarischer Revolution (Frankfurt: Verlag Neue Kritik, 2008), 392-414. On Marx's notion of general intellect and Hans-Jürgen Krahl, see Franco "Bifo” Berardi, The Soul at Work: From Alienation to Autonomy (New York: Semiotext[e], 2009), 58-70. The concept of the general intellect would come to play a central role in the context of Italian post-operaismo.

20. In December 1976, after Lebovici rejected his manuscript, Jaime Semprun sent Debord a letter, addressing him as "coresponsible" because of his position at Champ Libre. Debord rejected any suggestion that he was somehow (co)directing Champ Libre, stating that he came to join the publisher "belatedly," in the summer of 1971, when Champ Libre had already acquired a subversive prestige. Debord is no doubt correct in this regard, and he understandably felt a need to fight grotesque accounts of his "sinister" influence over Lebovici, as if the latter were Debord's sock puppet. However, from 1971 to 1974, when the editorial équipe around Gérard Guégan was fired by Lebovici, Debord's influence steadily grew thanks to his developing friendship with Lebovici and Lebovici’s wife, Floriana. After the departure of the "Guéganists,” Floriana took control of the day-to-day operations.

21. After the assassination of Lebovici in 1984, the company was renamed Éditions Gérard Lebovici in his honor. After Floriana Lebovici's death in 1990, Debord left the publishing house, which was dissolved, and its backlist was taken over by the newly founded Editions Ivrea.

22. Debord also suggested ways to combine the publisher's different lists. The combination of lists F, D, and S, for instance, would create a sequence from "The Russian Avant-Garde and dada” via “The SI and '68” to "The Consequences of '68. "Guy Debord to Floriana Lebovici, 29 March 1986, in Correspondance, vol. 6 (Paris: Arthème Fayard, 2006), 397-400.

23. In a letter dated September 6, 1976, Debord congratulates Lebovici on the 
"perfect" ad, placed in an issue of Le Monde teeming with "symptoms of a universal decadence." Debord, Correspondance, vol. 5, 363. In a short text purportedly written by Lebovici and which a disgruntled Mustapha Khayati attempted to insert into Champ Libre's edition of La misère en milieu étudiant in October 1976, Khayati includes a mocking reference to this ad, treating it as a symptom of delusions of grandeur. See Éditions Champ Libre, Correspondance, vol. 1 (Paris: Champ Libre, 1978), 35.

24. Karl Marx, Outlines of the Critique of Political Economy, trans. Martin Nicolaus, Marxists Internet Archive, http://www.marxists.org/archive/marx/works/1857/grundrisse/ch01.htm; Marx, Grundrisse, 27.

25. See Guy Debord to the Cercle de la Librairie, 27 June 1963, in Correspondance, vol. 2 (Paris: Arthème Fayard, 2001), 244-247.

26. From 1978 on, when the first volume was published, correspondents were warned that their letters might show up in a future volume. See the ironic reference in a letter from Hanna Mittelstadt and Lutz Schulenburg of Edition Nautilus in Éditions Champ Libre, Correspondance, vol. 2 (Paris: Champ Libre, 1981), 82.

27. See Debord, Correspondance, vol. 5, 85, 325.

28. Mary Ann Doane, "The Location of the Image: Cinematic Projection and Scale in Modernity," in Art of Projection, ed. Stan Douglas and Christopher Eamon (OstfildernRuit, Germany: Hatje Cantz, 2009), 151.

29. Doane, "The Location of the Image," 164.

30. Internationale situationniste 8 (December 1960): 8. A photo from a different angle is published in Robert Ohrt, Phantom Avantgarde: Eine Geschichte der Situationistischen Internationale und der modernen Kunst (Hamburg: Edition Nautolus, 1990), 232.

31. Christophe Bourseiller, Vie et mort de Guy Debord 1931-1994 (Saint-Malo, France: Pascal Galodé, 2012), 178-183.

32. See Ohrt, Phantom Avantgarde, 232.

33. The "spectator becoming actor" was a concern of Debord's erstwhile Lettrist colleague Marc'O. 'Le spectateur devient peu à peu acteur, s'agite avec le film qui devient secondaire" (The spectator becomes little by little an actor, grows restless with the film which becomes secondary). Marc'O [Marc-Gilbert Guillaumin], "Introduction au cinéma nucléaire," ION 1 (April 1952): 245.

34. Guy Debord, In girum imus nocte et consumimur igni (1978), trans. Ken Knabb, in Guy Debord, Complete Cinematic Works (Oakland, CA: AK Press, 2003), 133. The original French script is in Guy Debord, Oeuvres cinématographiques complètes (1994), 193.

35. Guy Debord to Gianfranco Sanguinetti, 2 May 1974, in Correspondance, vol. 5, 147-149.

36. Debord, In girum, 134. For the original French, see Debord, Oeuvres cinématographiques complètes (1994), 194-195.

37. The cinema in question is the Quintette Pathé in the rue de la Harpe on the Left Bank. The photo of the cinema is published in the booklet accompanying the DVD set Oeuvres cinématographiques complètes (Paris: Gaumont, 2005), 81.

38. Bourseiller, Vie et mort de Guy Debord, 398. The program consisted of Sur le passage and La société du spectacle from Wednesday to Saturday, and Réfutation de tous les jugements, tant élogieux qu'hostiles, qui ont été jusqu'ici portés sur le film "La Société du Spectacle" (Refutation of all the judgments, pro or con, thus far rendered on the film "The Society of the Spectacle," 1975) and In girum from Sunday to Monday. See Guy Debord to Gérard Lebovici, 11 September 1983, in Correspondance, vol. 6 (Paris: Arthème 
Fayard, 2006), 243.

39. A "reconstruction as impoverished and false as this botched tracking shot." Debord, "On the Passage," http://www.bopsecrets.org/SI/debord.films/passage.htm; translation modified.

40. Debord, In girum, 146. For the original French, see Debord, Oeuvres cinématographiques complètes (1994), 212.

41. Benjamin Noys, "Guy Debord's Time-Image: In girum imus nocte et consumimur igni (1978)," in this issue of Grey Room.

42. The second volume of Debord's late autobiographical exercise, Panégyrique (1997), combines an aerial photo of Paris with a quotation from Johan Huizinga's The Waning of the Middle Ages about the change effected by the increasing importance given to the visual remains of the past: the past became more serene because "the visual arts do not lament.” Guy Debord, Panégyrique (Paris: Fayard, 1997), n.p.; my translation.

43. Rod Dickinson, "Why I Hate Playing the Game of War" (unpublished manuscript, n.d., written as part of a correspondence with Richard Barbrook).

44. Guy Debord to Gérard Lebovici, 8 March 1978, in Correspondance, vol. 5, 451.

45. Dickinson, "Why I Hate Playing the Game of War."

46. Arguing that the spectator is always already active, Jacques Rancière has attacked the Feuerbachian underpinnings of Debord's notion of the spectacle and states that "looking is already an action" and " interpreting the world' is already a means of transforming it, of reconfiguring it.” Jacques Rancière, “The Emancipated Spectator,” Artforum 45, no. 7 (March 2007): 277. Granted: Debord pays insufficient attention to the different modalities of spectatorship in what he termed "the spectacle." Furthermore, the quintessential avant-garde project of the "emancipation of the spectator" can seem dirigiste andhorror of horrors-proto-totalitarian to the contemporary observer. But although stating that the spectator is always already active and emancipated may seem enlightened, Rancière's position seems to frustrate attempts at differentiation between subject positions even more than does Debord's Manichaean opposition between spectacle and playful life. At least Debord had two categories rather than one, and two might be the beginning of a series.

47. In a 1972 letter to Lebovici, Debord points out the nineteenth-century (public domain) French translations of Clausewitz's writings. Guy Debord to Gérard Lebovici, 16 April 1972, in Correspondance, vol. 4 (Paris: Arthème Fayard, 2004), 541-542.

48. Guy Debord to Gérard Lebovici, 24 May 1976, in Correspondance, vol. 5, 351

49. Pamela M. Lee, “New Games,” Australian and New Zealand Journal of Art 10, no. 1 (2010): 39.

50. Norbert Wiener, Human Use of Human Beings: Cybernetics and Society (Cambridge, MA: Da Capo, 1954), 181.

51. Class Wargames, Guy Debord's The Game of War (2011), http://www.classwargames.net/?page_id=149.

52. On the Seven Years' War, see Debord, Correspondance, vol. 5, 531. Vladimir Lenin used Clausewitz's theory of war as a model for revolutionary war, an obvious precedent for Debord. See Tony Cliff, Building the Party, vol. 1 of Lenin (London: Pluto Press, 1975), ch. 14, http://www.marxists.org/archive/cliff/works/1975/lenin1/chap14.htm\#s6.

53. Dickinson, "Why I Hate Playing the Game of War."

54. Alexander Galloway, lecture at Mediamatic, Amsterdam, 25 October 2007. For a summary of the lecture, see Anne Helmond, "Alexander Galloway-The Game of 
War @ Mediamatic, Amsterdam,” New Media Research Blog, 27 October 2007, http://www.annehelmond.nl/2007/10/27/alexander-galloway-the-game-of-war-mediamatic-amsterdam/.

55. "A work works by not working at all." Paul Chan, "A Lawless Proposition," e-flux journal 30 (December 2011), http://www.e-flux.com/journal/a-lawless-proposition/. 